УДК: 792 / 796.4

Dmitriy V. Orel,

Senior Lecturer of the Department of circus genres, Kyiv Municipal Academy of Variety and Circus Arts,

Kyiv, Ukraine

ORCID: 0000-0002-2413-1676

\title{
SYSTEMATIC TRAINING OF PROFESSIONAL CIRCUS ARTISTSE (ACROBATS-VOLTIGERS AND AIR GYMNASTS ON THE CORDE-DE-PÉRIL) IN THE INSTITUTION OF HIGHER EDUCATION OF ART SPHERE
}

\begin{abstract}
The article outlines the possibility of a systematic principle of training a circus artist in today's conditions.

The purpose of the study is to systematically review the training of the future professional circus artist - an acrobat and gymnast. The system of humanitarian, artistic, pedagogical, scientific and professional competencies is traced. The specificity and characteristics of the educational process in the circus industry are determined.
\end{abstract}

The research methodology is based on the desire for an integrated approach to the study of circus culture of related art forms. In addition, empirical, descriptive, and general scientific methods of comparative analysis and synthesis are used. A The scientific novelty consists to identify the characteristic features of specificity and the training of a professional circus artist in genres - acrobatic voltage and air gymnastics on the cord de péril.

The circus culture in the process of evolution is enriched with the modern interaction of the performing arts: from introducing stunt elements from sports acrobatics and gymnastics; contemporary theater, in particular acting and psychophysical training; neoclassical ballet school and popular youth styles in contemporary choreography with the borrowing of modern dance, jazz dance; plastic and facial 
aspects of the school of contemporary pantomime; circus genres manual balancing, juggling, as well as the humanities and art cycle of instruction. The uniform load of the professional cycle in combination with the artistic and humanitarian opens up new opportunities in the preparation of a contemporary circus artist with professional skills. The emphasis on the student's use while learning the great possibilities of modern technologies for independent work is electronic sites, video presentations, master classes, training and practical training, creative events create unlimited opportunities for becoming a professional circus artist in the modern labor market, both in Ukraine and abroad.

Statement of the problem. The article outlines the possibility of a systematic principle of training a circus artist in today's conditions.

The methodology is based on the desire for an integrated approach to the study of circus culture of related art forms. In addition, empirical, descriptive, and general scientific methods of comparative analysis and synthesis are used. Scientific novelty strives to identify the characteristic features of specificity and the training of a professional circus artist in genres - acrobatic voltige and aerial gymnastics on the cord de péril.

Analysis of research and publications on this issue. Formal-technical, as well as historical aspects and features and specifics of circus genres are analyzed in scientific works - Mikhail Bakhtin, Walter Zapashny, Alexander Kiss. In these works, the historical aspects of circus genres were described and determined acrobatics, gymnastics, juggling, trainers, clowning. The historical periods, personalities, as well as the uniqueness of work in specific genres of circus art in the XX-th century were covered.

Domestic circus art is represented by works by Mikhail Rybakov, Vladimir Kashevarov, Yuriy Kashuba, Anatoly Stetsenko, Svetlana Dobrovolskaya, Kapitolina Dementieva, Marina Malykhina, Denis Sharikov, Julia Romanenkova, Maxim Golovchenko. In the work of Mikhail Rybakov, a huge analysis of the historical process 
of the Kiev Circus was carried out. The periods, circus genres are described - acrobatics, aerial gymnastics, equilibristics, clowning, pantomime, tricks, juggling, original circus genres. The unique tricks and techniques of prominent circus artists of the $\mathrm{XX}^{\text {th }}$ century are described.

In the work by Mikhail Rybakov an analysis is given of the creators of Russian national circus, the academy of circus art, entrepreneurs and artists, the theater of animals, circus art and the life of Kiev, the Ukrainian circus collective, and the circus on the stage [3].

The work by Vladimir Kashevarov describes the features of stage technical training and safety techniques in circus genres. In particular acrobatics and aerial gymnastics. The characteristics of circus apparatuses, the specifics of suspension mechanisms and fixtures are analyzed. Instructions are given for circus artists to use circus props. This work is unique in its kind, among the new editions of Ukraine on the specifics of circus art [2].

In the work of Yuri Kashuba, the stage method for preparing an acrobatic couple is analyzed, examples of the stunt part are given, and movements are described. Comments and work on errors in performing acrobatic elements are given [4].

In the work by Anatoly Stetsenko and Svetlana Dobrovolskaya [5], for the first time in circus criticism, the features of the work and the specifics of aerial gymnastics on the trapeze are indicated. Trick elements, execution rules, historical features of this circus genre, as well as the stage method of teaching work on the genre are indicated.

Purpose of the article is to systematically review the training of the future professional circus artist - an acrobat and gymnast. The system of humanitarian, artistic, pedagogical, scientific and professional competencies is traced. The specificity and characteristics of the educational process in the circus industry are determined. 
Statement of the basic material. Today's market in the field of circus art, in particular acrobatics and gymnastics, dictates new requirements for the professional training of artists of these circus genres. An attempt to implement on the basis of the Kiev Municipal Academy of Variety and Circus Arts, the Faculty of Variety and Circus Arts, the Department of Circus Genres, as well as the State Enterprise of the National Circus a systematic training of a professional circus artist - an acrobat voltigeur and an air gymnast on cord de péril. The system of training students of the first educational degree «Bachelor» is provided in accordance with regulatory documents of the Ministry of Education and Science of Ukraine and the State educational standard in the specialty 026 (Stage Art), as well as the educational professional program «Circus Genres».

It is important to note that the professional training system for the educational professional program at the Kiev Municipal Academy of Variety and Circus Arts is carried out according to such qualifications - circus acrobat, air gymnast, juggler, illusionistmagician, artist of the mimicry and jet theater, circus clown comedian, and teacher.

The purpose of the educational program is to train highly qualified circus artists, teachers of circus disciplines, combining professional performing skills in contemporary public and private circus companies, circus show programs with the ability to provide high-quality educational process through teaching in an educational institution.

Features of the program are the training of highly qualified circus artists by mastering a range of educational components: specialization in genres, acrobatics, gymnastics, juggling, pantomime, movement plastic, pedagogy, acting, circus performers, basics of stage and circus performance, theater history, circus history, make-up in a professional direction, aimed at the comprehensive development, creative implementation and 
universality of the future circus artist and teacher in the field of circus and stage genres.

Teaching and learning programs - student-centered and dual learning, self-study. Lectures, practical, individual lessons, independent work of the student. Scientific activity (by organizing and attracting students to participate in scientific and practical conferences, seminars, master classes, round tables) creative activity (participation in cultural and educational events: concerts, competitions, festivals), pedagogical, industrial training, undergraduate (performing) practice.

The student assessment system is oral and written tests, differentiated tests, exams; creative exams in the form of practical closed or open shows; concert activity; creative projects; current control; certification in the form of a demonstration of qualification work and a comprehensive exam on the history of the circus, pedagogy, teaching methods of professional disciplines; protection of term papers and practices.

Software Competencies. Integral competency is the ability to solve complex specialized tasks in the field of stage art (circus genres) both independently and as part of a creative team, involving creative, material, technical, financial, economic and other resources and applying theories and methods of art, theater (circus) pedagogy, psychology of creativity.

General competencies: ability to abstract thinking, analysis and synthesis; ability to apply knowledge in practical situations; domain knowledge and understanding and understanding professional activity; ability to communicate in the state language both orally and in writing; ability to communicate in a foreign language; skills in using information and communication technologies; ability to be critical and self-critical; ability to adapt and act in a new situation; the ability to generate new ideas (creativity) the ability to identify, pose and solve problems; ability to make informed decisions; ability to work in a team; interpersonal 
skills, the ability to motivate people and move towards a common goal.

\section{Professional competencies:}

1. the ability to solve complex problems in the field of circus innovation with a deep rethinking of existing and the creation of new holistic knowledge and professional practice in the field of stage art;

2. the ability to generate an idea and carry out the development of a new artistic idea and its embodiment in a work of circus art;

3. the ability to publicly present the result of their creative (intellectual) activities;

4. the ability to work effectively in a team in the process of creating a circus work that is synthetic in nature, guides work, or participates in a creative group in the process of its preparation;

5. the ability to professionally master the informative (informational, expressive-figurative) levels of the circus piece;

6. the ability to creatively perceive the world and the ability to reproduce it in artistic scenic images in circus art;

7. the ability to operate with a specific system of expressive means (plastic-visual, sound, acting and executive, editing and composition, screenwriting and drama) in the creation and production of works of stage art (for circus specializations);

8. the ability to understand and evaluate relevant cultural processes (in circus genres);

9. the ability to operate with the latest information and digital technologies in the process of implementing an artistic idea and understanding the creative result;

10. the ability to choose the appropriate creative means of artistic (circus) statements;

11. the ability to correlate a personal understanding of an artistic idea and work with an external context;

12. the ability to critically analyze, evaluate and synthesize new complex ideas in creative production circus activities; 
13. ability to initiate innovative stage projects, festival and competition activities, promotion of the best examples of national and world circus heritage;

14. the ability to communicate in dialogue with a wide professional and scientific community and the public in the field of stage art and production, to interact with representatives of other creative professions;

15. the ability to transfer knowledge of stage art and practical experience in a variety of ways and means;

16. the ability to develop and implement educational projects with the aim of popularizing circus art (by specialization) in wide sections of society, including using the capabilities of the theater press, television, and the Internet;

17. the ability to work with professional literature, to analyze works of literature and art, using professional circus terminology.

Further we will analyze the specific features of professional competencies specifically for acrobat voltigeur and an air gymnast on cord de péril.

The ability to professionally perform with specialization in the genre:

on circus acrobatics (voltage): acrobatic track, bridge, springboard, lounge, mat, bagel, foray, pace, jump, rondat, wheel, flip, flik flak, back and front somersault, flip-flop, somersault, somersault. (somersault), beer pirouette, pirouette, one and a half pirouettes, double somersaults, partners, vaulting exercises, supports (etude exercises), tempo support, emphasis, stand, foot stand, turn, kurbet, beer flip, balance, jump; acrobatic track, insurance, lounge, mat, rack, frogman, twine, pace jump, wheel, coup, cities, somersault, Courbet, transfer, kopfshprung, wheel, rondat, fordersprung, flick-flak, somersault, grab, entry, jump [3].

In circus gymnastics (cord de parel): effective techniques for maintaining body balance. Correctly carry out a warm-up with the inclusion of simple gymnastic exercises. Correctly apply the insured funds necessary for both learning and performing gymnastic 
elements and exercises - rope climbing, cockbet, mill, blanche, flag and bookmarks, clippings, support legs and arms, balance. Correctly perform both simple and complex gymnastic elements and exercises on the cord de parel. Correctly analyze your own technique of performing gymnastic elements and exercises, be able to find and correct errors of a technical nature in time. Based on the acquired program material on gymnastics, to be able to correctly compose and perform simple and reinforcing gymnastic combinations [2].

Full implementation of the training system for professional circus artists requires the mastery of the following special disciplines by students.

Ability to perform professionally:

- acrobatics and gymnastics: elementary stands on the head and arms, elementary jumps, somersaults, wheels, difficult somersaults, complex jumping combinations, acrobatic eccentricity, blanche, half props, exercises on gymnastic bars, gymnastic rings, gymnastic horizontal bar, gymnastic crossbeam (low), insurance, lounge, mat, grasp, jump, east, emphasis, swing, recession, rise, step, balance, strength exercises, balance exercises, vault, somersault (roll), wheel, transfer, turnover, flip, flip stand, vis, seed, sit down;

- juggling: juggling balls, rings, clubs; juggling with cross throws, juggling in pairs, separately in each hand;

- dance: classical staging of the body, arms, head and legs; mastering the primary skills of coordination of movements from classical dance; understanding of basic concepts in the terminology of classical dance, exercises at the machine tool and in the middle of the hall, jumping in classical dance technique (French); folk stage dance main characteristics and manner of performance in Ukrainian, Spanish, Polish, Italian, Mexican, Oriental character. To be able to practically perform elements of modern dance - Graham, Lemon, Cunningham techniques, jazz techniques, hip-hop techniques, contemporary dance; own basic dance elements, move freely and combine individual movements into dance studies, perform one or another dance according to the peculiarities of the style and character 
of the choreographic style - modern, jazz, street dance; learn to distinguish the nature of music, its size, stylistic basis, be able to move clearly to the musical accompaniment; develop your creativity and become accustomed to independent work; move freely and combine individual movements into dance studies, perform one or another dance according to the peculiarities of the manner and character of the choreographic style; learn to distinguish the nature of music, its size, stylistic basis;

- pantomimes and plastics of movement transtation, lagging and leading movements, forward and backward waves, side waves, balance, traction and hooks, fixed point, fixed plane, level, angles,motion characteristic: amplitude, direction, strength, imaginary forces and obstacles, plastic composition, metamorphosis of movement, imaginary environment, facial expressions, mask, gesture, plastic characterization of the image, character, rapid, puppet, cartoon, robot, prickly, chopping, anti-movement;

- acting skills of the circus artist (laws, techniques, principles, sections) elements of the internal and external equipment of the circus artist; method of working on an image in a circus number; the main stages and content of the circus artist's homework on the role; main concepts of the course: proscenium, act, actor, arena, analysis (dramatic, effective, ideological and thematic), ensemble, apparatus, intermission, architectonics, attraction, biomechanics, props, performance, hero, game, diction, dynamism, dialogue, mirror scenes, dramaturgy, duet, eccentric, episode, epilogue, etude, genre, gesture, proposed circumstances, idea, improvisation, imitation, inversion, interpretation, intrigue, keynote, lyceum, conflict, skill, method, mise-en-scene, monologue, editing, through action, image (artistic, stage, ma monthly), pause, score, reincarnation of I, experiences, character, role perspective, subtext, event, psychophysical apparatus, prologue, re-launch, promo, reactivity, ramp, props, repertoire, rehearsal, replica, retrospective, reflectivity, rhythm, sensitivity, style, plot, theater, theatricalization, 
theme, pace, tempo, type, imagination, plot, fragment, character, characterization, stamp, diary, attention, phenomenon.

Freely navigate in the directions, styles, genres and types of stage art (pop, circus, theater); the basics of directing a circus show; know the terminological and conceptual apparatus in the specialty; creative heritage of outstanding masters.

Conclusions. The circus culture in the process of evolution is enriched with the modern interaction of the performing arts: from the introduction of stunt elements from sports acrobatics and gymnastics; modern theater, in particular acting and psychophysical training; neoclassical ballet school and popular youth styles in modern choreography with the borrowing of modern dance, jazz dance; plastic and mimic aspects of the school of modern pantomime; circus genres - juggling, as well as the humanitarian and art cycle of instruction. The uniform load of the professional cycle in combination with the artistic and humanitarian opens up new opportunities in the preparation of a modern circus artist with professional skills. The emphasis on the student's use during training the great opportunities of modern technologies for independent work - electronic networks, video presentations, master classes, training and production practice, creative events create unlimited opportunities for becoming a professional circus artist in the modern labor market, both in Ukraine and abroad.

Thus, only with systematic training of circus artists acrobatic voltige and aerial gymnastics on the cord de péril who study in the specialty 026 Stage art in the first educational degree, Bachelor, educational professional program of Circus genres, Academy students have a great chance to become a serious cocurrent environment in circus companies of the world, as well as the best decoration of a domestic circus.

\section{References}

1. Kashevarov $V$., Orel D. Scenichno-tekhnichna pidgotovka $\mathrm{v}$ cirkovih zhanrah: tekhnika bezpeki, manezh, rekvizit [Stage and 
technical training in circus genres: safety equipment, playpen, props]. Kyiv: KMAETI, 2018. 75 s. (in Ukrainian)

2. Rybakov M. Kievskij cirk: lyudi, sobytiya, sud'by [Kiev Circus: people, events, destinies]. Kyiv: Attica, 2006. 300 s. (in Rusian)

3. Tcirkovye terminy [Circus terms]. Available at: http: //curcus.narod.ru/termin.htm (in Russian])

4. Kashuba Yu. Specific features of circus acrobatics: power acrobatics, analysis of the scenic method in the Kiev Municipal Academy of Variety and Circus Art//Innovative solutions in modern science. 2018. 6 (25). Pp. 100-105. (in English)

5. Stetsenko A., Dobrovolskaya S. Specific features of the scenic method in the genre «Circus Gymnastics»: formal technical characteristics, as well as analysis of tricks on «Shvung Trape» (trapezium)// Innovative solutions in modern science, 6 (25), 2018. Pp. 95-99 (in English)

\author{
Дмитро Володимирович Орел, \\ старший викладач кафедри циркових жанрів, \\ Київська муніципальна академія \\ естрадного та циркового мистецтв, \\ Київ, Україна \\ ORCID: 0000-0002-2413-1676
}

\title{
СИСТЕМНА ПІДГОТОВКА ПРОФЕСІЙНИХ АРТИСТІВ ЦИРКУ (АКРОБАТІВ-ВОЛЬТИЖЕРІВ ТА ПОВІТРЯНИХ ГІМНАСТІВ НА КОРД-ДЕ ПАРЕЛІ) У ЗАКЛАДІ ВИЩӦ̈ ОСВІТИ МИСТЕЦЬКОГО СПРЯМУВАННЯ
}

Анотація. У статті викладено можливість системного принципу підготовки циркового артиста в умовах сьогодення. Мета дослідження полягає в системному розгляді підготовки майбутнього професійного артиста циркових жанрів - акробата 
та гімнаста. Простежено систему гуманітарних, художніх, педагогічних, наукових та фахових компетенцій. Визначені специфіка i характеристика освітнього процесу у цирковій галузі. Методологія дослідження грунтується на застосуванні комплексного підходу до вивчення цирокової культури суміжних видів мистецтв. Крім того, використовуються емпіричні, описові та загальнонаукові методи компаративного аналізу й синтезу. Наукова новизна полягає у виявленні характерних особливостей специфіки та підготовки професійного артиста цирку за жанрами - акробатичний вольтиж та повітряна гімнастика на корд-де-парель. Циркова культура у процесі еволюції збагачувалась наслідками сучасної взаємодії мистецтв: від укорінення трюкових елементів спортивної акробатики та гімнастики, сучасного театру, зокрема акторської майстерності та психофізичного тренінгу, неокласичної балетної школи та популярних молодіжних стилів у сучасній хореографії із запозиченням модерн-танцю, джазтанцю, пластичного та мімічного аспектів школи сучасної пантоміми, циркових жанрів - ручної еквілібристики, жонглювання, а також гуманітарного та мистецького циклів навчання. Рівномірне навантаження професійного циклу в поєднанні 3 мистецьким та гуманітарним відкриває нові можливості у підготовці сучасного циркового артиста 3 професійними вміннями та навичками. Також акцентування на використанні студентом під час навчання великої можливості сучасних технологій для самостійного навчання - електронні мережі, відео презентації, майстер-класи, навчальна та виробнича практика, творчі заходи створюють необмежені можливості для становлення професійного артиста цирку на сучасному ринку праці, як в Україні, так і за кордоном.

Ключові слова: циркові жанри, акробатика, гімнастика, вольтиж акробатичний, повітряна гімнастика на корд-де-парель, цирковий трюк, сценічна репрезентація, цирковий номер, хореографія, пантоміма. 


\begin{abstract}
Література
1. Камеваров В., Орел Д. Сценічно-технічна підготовка в циркових жанрах: техніка безпеки, манеж, реквізит. Київ: КМАЕЦМ, 2018. 75 с.

2. Рыбаков М. Киевский цирк: люди, события, судьбы. Киев: Атика, 2006. 300 с.

3. Цирковые термины. URL: http:// curcus.narod.ru/termin.htm

4. Kashuba Yu. Specific features of circus acrobatics: power acrobatics, analysis of the scenic method in the Kiev Municipal Academy of Variety and Circus Art//Innovative solutions in modern science, 2018, 6 (25). Pp. 100-105.

5. Stetsenko A., Dobrovolskaya S. Specific features of the scenic method in the genre "Circus Gymnastics»: formal technical characteristics, as well as analysis of tricks on «Shvung Trape» (trapezium)// Innovative solutions in modern science, 2018, 6 (25). Ss. 95-99.
\end{abstract}

\author{
Дмитрий Владимирович Орел, \\ старший преподаватель кафедры цирковых жанров, \\ Киевская муниципальная академия \\ эстрадного и циркового искусств, \\ Киев, Украина \\ ORCID: 0000-0002-2413-1676
}

\title{
СИСТЕМНАЯ ПОДГОТОВКА ПРОФЕССИОНАЛЬНЫХ АРТИСТОВ ЦИРКА, АКРОБАТОВ-ВОЛЬТИЖЕРОВ И ВОЗДУШНЫХ ГИМНАСТОВ НА КОРД-ДЕ ПАРЕЛЬ В ЗАВЕДЕНИИ ВЫСШЕГО ОБРАЗОВАНИЯ ХУДОЖЕСТВЕННОГО НАПРАВЛЕНИЯ
}

Аннотация. В статье изложена возможность системного принципа подготовки циркового артиста в условиях сегодняшнего дня. 
Цель исследования заключается в системном рассмотрении подготовки будущего профессионального артиста цирковых жанров - акробата и гимнаста. Прослежено систему гуманитарных, художественных, педагогических, научных и профессиональных компетенций. Определены специфика и характеристика образовательного процесса в цирковой отрасли. Методология исследования основывается на применении комплексного подхода к изучению цироковой культуры, смежных видов искусств. Кроме того, используются эмпирический, описательный и общенаучные методы компаративного анализа и синтеза. Научная новизна состоит в выявлении характерных особенностей специфики и подготовки профессионального артиста цирка по жанрам - акробатический вольтиж и воздушная гимнастика на корд-де-парель. Цирковая культура в процессе эволюции обагащается современным взаимодействием сценических искусств: от внедрения трюковых элементов из спортивной акробатики и гимнастики; современного театра, в частности актерского мастерства и психофизического тренинга; неоклассической балетной школы и популярных молодежных стилей в современной хореографии с заимствованием модерн-танца, джаз-танца, пластического и мимического аспектов школы современной пантомимы, цирковых жанров - ручной эквилибристики, жонглирования, а также гуманитарного и художественного циклов обучения. Равномерная нагрузка профессионального цикла в сочетании с художественным и гуманитарным открывает новые возможности в подготовке современного циркового артиста с профессиональными умениями и навыками. Также акцентирование на использование студентом во время обучения больших возможностей современных технологий для самостоятельной работы - электронные сети, видео презентации, мастер-классы, учебная и производственная практика, творческие мероприятия создают неограниченные возможности для становления профессионального артиста 
цирка на современном рынке труда, как в Украине, так и за рубежом.

Ключевые слова: цирковые жанры, акробатика, гимнастика, вольтиж акробатический, воздушная гимнастика на корд-де-парель, цирковой трюк, сценическая репрезентация, цирковой номер, хореография, пантомима. 